\title{
Sulfated bromophenols from Osmundaria obtusiloba (C. Agardh) R. E. Norris (Rhodophyta, Ceramiales)
}

\author{
LUCIANA RETZ DE CARVALHO ${ }^{1,3}$, SILVIA M.P. DE BEAUCLAIR GUIMARÃES ${ }^{1}$ and \\ NIDIA FRANCA ROQUE ${ }^{2}$
}

(received: November 10, 2005; accepted: July 27, 2006)

\begin{abstract}
Sulfated bromophenols from Osmundaria obtusiloba (C. Agardh) R. E. Norris (Rhodophyta, Ceramiales)). Two new sulfated oligobromophenols from the marine red algae Osmundaria obtusiloba, 4-(1'-potassium sulfate, 2,3-dibromo, 1',4,5-trihydroxybenzyl) - 4"'-(1"'-potassium sulfate, 2",3"'-dibromo, 1"',4", 5"'-trihydroxybenzyl) sulfate and 1'-(2, 3-dibromo, 4-potassium sulfate, 1', 4, 5-trihydroxybenzyl) - 4"'-(1'” potassium sulfate, 2", 3"'-dibromo, 1"', 4", 5" trihydroxybenzyl) sulfate, are herein reported. Besides them it was obtained 2, 2', 3, 3'-tetrabromo-4, 4', 5, 5'-tetrahydroxydiphenylmethane, 2, 3-dibromop-hydroxybenzyl methyl ether (methyl lanosol), dipotassium 2,3-dibromo-5-hydroxybenzyl 1',4-disulfate, 24-methylenecolest5-en-3- $\beta$-ol and $\alpha$-D-mannopyranosyl-( $\left.1 \rightarrow 2^{\prime}\right)$-glycerate (digeneaside). The structures were determined by analysis of the spectroscopic data (IR, NMR and MS) and comparison with the literature. The ${ }^{13} \mathrm{CNMR}$ data for dipotassium 2,3-dibromo5-hydroxybenzyl-1',4-disulfate are described here for the first time. The present study also suggests a mild method to isolate and to purify sulfated compounds.
\end{abstract}

Key words - digeneaside, lanosol, Osmundaria obtusiloba, Rhodophyta, sulfated bromophenols

RESUMO - (Bromofenóis sulfatados de Osmundaria obtusiloba (C. Agardh) R. E. Norris (Rhodophyta, Ceramiales)). O estudo químico de Osmundaria obtusiloba (Rhodophyta, Ceramiales) resultou no isolamento de dois novos oligobromofenóis sulfatados, o 4"'-(1'”-sulfato de potássio, 2",3"'-dibromo, 1"',4",5"'-trihidroxibenzil) sulfato de 4-(1'-sulfato de potássio, 2,3-dibromo, 1',4,5-trihidroxibenzila) e o 4"'-(1"'-sulfato de potássio, 2", 3"'-dibromo, 1'”,4",5"'-trihidroxibenzil) sulfato de 1'-(2,3-dibromo, 4-sulfato de potássio, 1',4,5-trihidroxibenzila), além dos já conhecidos 2, 2', 3, 3'-tetrabromo-4, 4', 5, 5'-tetraidroxidifenilmetano, éter metílico do álcool 2, 3-dibromo-4, 5-diidroxibenzílico (metilato de lanosol), 1',4-dissulfato de potássio do 2,3-dibromo-1',4, 5-trihidroxibenzila, 24-metilenocolest-5-en-3- $\beta$-ol e ácido $\alpha$-D-manopiranosil-(1 $\rightarrow 2$ ')-glicérico (digeneasídeo). As análises estruturais dessas substâncias foram efetuadas com base nos dados espectroscópicos (IV, RMN e EM) e comparação com aqueles existentes na literatura. Os dados de RMN de ${ }^{13} \mathrm{C}$ para o 1',4-dissulfato de potássio do 2,3-dibromo-1',4, 5-trihidroxibenzila estão sendo descritos aqui pela primeira vez. O presente trabalho também sugere um método brando para isolamento e purificação de substâncias sulfatadas.

Palavras-chave - bromofenóis sulfatados, digeneasídeo, lanosol, Osmundaria obtusiloba, Rhodophyta

\section{Introduction}

Sulfated compounds are common in the marine environment but among the metabolites of red seaweeds there are few known sulfated molecules other than polysaccharides (Kornprobst et al. 1998). Specifically in the family Rhodomelaceae, besides these polysaccharides produced as cell wall constituents, the only sulfated metabolites reported until now are dipotassium 2,3-dibromo-5-hydroxy benzyl-1',4-disulfate and disodium 2, 3, 6-tribromo-5-hydroxy-1',4-disulfate

\footnotetext{
1. Instituto de Botânica, Seção de Ficologia, Caixa Postal 4005, 01061-970 São Paulo, SP, Brasil.

2. Instituto de Química, Universidade Federal da Bahia, 40170-290 Salvador, BA, Brasil.

3._Corresponding author: lretz@uol.com.br
}

(Faulkner 1984, 1986, 1990, 1991, 1992, 1993, 1996, 1998, 2000, 2001, 2002, Higa 1981, Kurata \& Amiya 1980). The first one was isolated from Halopithys, Odonthalia, Polysyphonia, Rhodomela and Osmundaria and the second was found only once, in Symphyocladia latiuscula. These two compounds are considered the precursors of the C-7 dihydroxylic bromophenols like 2, 3-dibromo-p-hydroxybenzyl alcohol (lanosol) and of oligobromophenols built-up of lanosol units (Higa 1981, Carvalho \& Roque 2000); these bromophenols constitute the single group of secondary metabolites produced by Halopithys, Odonthalia, Polysyphonia, Rhodomela, Osmundaria and Symphyocladia.

These compounds are considered a chemical defense mechanism against marine herbivorous animals (Kurata et al. 1997) but only few of them were isolated, unequivocally identified and evaluated for biological 
activities (Carvalho \& Roque 2000, Smit 2004). Of these substances that have been studied, lanosol shows antialgal and anti-inflammatory properties, it influences growth and morphology of marine macroalgae and stimulates seeds growth (Carvalho \& Roque 2000); the diarylmethane-type bromophenol of Odonthalia corymbifera has potent feeding-deterrent activity, and from the same species, two oligomeric bromophenols were found to be inactivators of $\alpha$-glycosidase (Kurata et al. 1997, Kuhiraha et al. 1999). Vidalol A and vidalol B are two anti-inflammatory oligobromophenols from Osmundaria obtusiloba (Wiemer et al. 1991).

Previous phytochemical investigations performed on species of Osmundaria resulted on the isolation of a halogenated diol (Kazlauskas et al. 1982), p-hydroxy benzyl alcohol, lanosol and vidalenone (Yoo 2002), $S$-methyl and $N$ - methyl compounds (Patti \& Morrone 1992) besides vidalol A and vidalol B (Wiemer et al. 1991).

The genus Osmundaria (Rhodophyta, Rhodomelaceae) comprises tropical, subtropical and warm temperate marine species. Osmundaria obtusiloba is distributed from the northeastern coast of Brazil up to Rio de Janeiro State.

Plant of Osmundaria obtusiloba (C. Agardh) R. E. Norris are characterized as follow: robust erect plants, $10-15 \mathrm{~cm}$ tall, axes flattened 3-4 mm wide, color dark red. Attached to the substratum by a discoid holdfast, ca. $1 \mathrm{~cm}$ diameter, giving rise to several flattened axes, ribbon-like, alternately-irregularly branched, with midrib conspicuous, margins smooth, apices involute. Internal structure composed of a central axial cell surrounded by 8 periaxial cells, 2 layers of medullary cells and a single-layered cortex. Midrib extensively corticated. Tetrasporangia structures borne in branchelets on the margins or on midrib proliferations.

The algae was found growing in the intertidal rock substratum in wave exposed sites at Parati beach, Anchieta County, Espírito Santo, forming a conspicuous population.

We here report the isolation of the two novel sulfated bromophenols 1 [4-(1'-potassium sulfate, 2,3-dibromo, 1',4,5-trihydroxybenzyl) - 4',-(1','-potassium sulfate, 2",3"'-dibromo, 1'”,4",5"'-trihydroxybenzyl) sulfate] and 2 [1'-(2, 3-dibromo, 4-potassium sulfate, 1', 4, 5trihydroxybenzyl) - 4"'-(1'”' potassium sulfate, 2"', 3'”dibromo, 1"', 4", 5" trihydroxybenzyl) sulfate], besides the known substances 3 (2, 2', 3, 3'-tetrabromo-4, 4', 5, 5'-tetrahydroxydiphenylmethane), 4 (2, 3-dibromo- $p$ hydroxybenzyl methyl ether) and 5 (dipotassium 2,3- dibromo-5-hydroxybenzyl 1',4-disulfate), in addition to 24 -methylenecolest-5-en-3- $\beta$-ol (6) and $\alpha$-Dmannopyranosyl-( $1 \rightarrow 2)$-glycerate $(7)$, from Osmundaria obtusiloba (Rhodomelaceae, Ceramiales) (figure 1). The substance 5 was first characterized in 1975 based only on the ${ }^{1} \mathrm{H}$ NMR and IR spectroscopy data (Weinstein et al. 1975). Herein, we had provided its ${ }^{13} \mathrm{C}$ NMR and mass spectra.

\section{Material and methods}

Plant material - Plants of Osmundaria obtusiloba (C. Agardh) R.E. Norris were collected from the intertidal rocks of Parati beach, Anchieta County, Espírito Santo State, in September 03, 1994 and authenticated by Dr. Silvia M. P. B. Guimarães of the Seção de Ficologia, Instituto de Botânica (SP, Brazil). A voucher specimen (SP 317880) was deposited in the herbarium of Instituto de Botânica (SP, Brazil).

Extraction and isolation of the compounds 1 to 7 - The dried algal material (278 g) was extracted with $\mathrm{MeOH}(4 \times 1.5 \mathrm{~L})$, the combined extracts were concentrated under vacuum. The residue (23 g) was suspended in $\mathrm{MeOH} / \mathrm{H}_{2} \mathrm{O}$ and partitioned successively with $n$-hexane and $\mathrm{CH}_{2} \mathrm{Cl}_{2}$. When $n$-hexane was added to the methanolic suspension, a precipitate was formed. This precipitate ( $4.3 \mathrm{~g}$ ) was removed and dried.

The $n$-hexane fraction (5.4 g) was applied onto a silica gel column, which was eluted with $\mathrm{CH}_{2} \mathrm{Cl}_{2} / \mathrm{MeOH}$ (gradient) to yield 100 fractions. Fraction 33 (168 mg) was further chromatographed on a Florisil column eluting with $\mathrm{CH}_{2} \mathrm{Cl}_{2}-\mathrm{MeOH}$ (gradient) to give compound $\mathbf{6}$ (16 mg).

The $\mathrm{CH}_{2} \mathrm{Cl}_{2}$ phase (3.2 g) was submitted to silica gel column chromatography using a step-wise gradient of $\mathrm{CH}_{2} \mathrm{Cl}_{2} / \mathrm{EtOAc} / \mathrm{MeOH}$. Material eluting with $\mathrm{CH}_{2} \mathrm{Cl}_{2}$ - $100 \%$ (340 mg) was further purified by Sephadex LH-20 to give $161 \mathrm{mg}$ of methyl lanosol (4). Chromatography on Sephadex $\mathrm{LH}-20$ of the fractions eluted with $\mathrm{CH}_{2} \mathrm{Cl}_{2} / \mathrm{EtOAc} / \mathrm{MeOH}$ (88:10:2) afforded substance 3 (3 $\mathrm{mg}$ ).

The hydroalcoholic phase from the partition was evaporated to remove $\mathrm{MeOH}$ and freeze-dried. It was obtained $7 \mathrm{~g}$ of dried material that was applied onto a column of Amberlite XAD-2 and fractionated according to Piertrzyk (1989). Material eluting with $\mathrm{H}_{2} \mathrm{O}$ was purified by passing through a Sephadex G-10 column to yeld $\mathbf{5}(9 \mathrm{mg})$.

The precipitate was fractioned by Amberlite XAD-2 (Piertrzyk 1989); the first fraction, eluted with $\mathrm{H}_{2} \mathrm{O}$, was further purified by Sephadex G-10 column, leading to the isolation of compounds 1 (120 mg), 2 (193 mg), and 7 (3.9 mg).

Acid hydrolysis of 2: compound 2 (100 $\mathrm{mg})$ was refluxed with $2 \mathrm{M} \mathrm{HCl}(20 \mathrm{~mL})$ on a steam bath $\left(70-80^{\circ} \mathrm{C}\right)$ for $1 \mathrm{~h}$. The reaction mixture was cooled, filtered, washed with water and dried. The hydrolysate $2 \mathrm{a}$ was analyzed by ${ }^{1} \mathrm{H}$ NMR.

Methylation of 2a and 4: hydrolysate 2a (50 mg) was treated with excess of diazomethane prepared according to the procedure described by Haraguchi (1991). The methylated 
<smiles>[Z6]Cc1cc(O)c(OS(=O)(=O)Oc2c(O)[14cH]c([13CH2][R5])c(Br)c2Br)c(Br)c1Br</smiles>

1<smiles>[3H]S(=O)(=O)C[14c]1[14cH][14c](Br)[14c](Br)[14c](OS(=O)(=O)OC)[14c]1O</smiles><smiles>Oc1cc(Cc2cc(O)c(O)c(Br)c2Br)c(Br)c(Br)c1O</smiles><smiles>[R]Oc1ccccc1</smiles>

$4 \mathrm{R}=\mathrm{Me} ; \mathrm{R}_{1}=\mathrm{H}$ $4 a \mathrm{R}=\mathrm{R}_{1}=\mathrm{H}$ 4b $\mathrm{R}=\mathrm{R}_{1}=\mathrm{Me}$<smiles>[Z6]OS(=O)(=O)Oc1c(O)c(O)c(C[14CH3])c(Br)c1Br</smiles>

5<smiles>[Z6]Oc1c(O)cc(C)c(Br)c1[O+]</smiles>

2

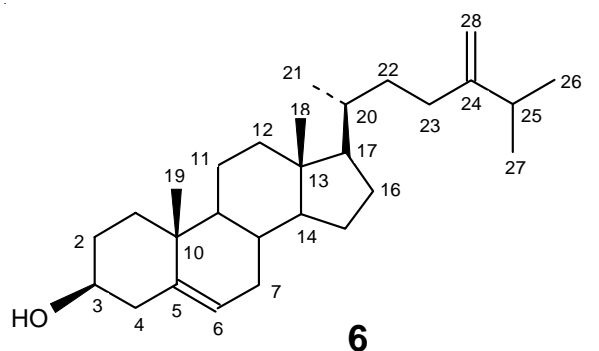

6

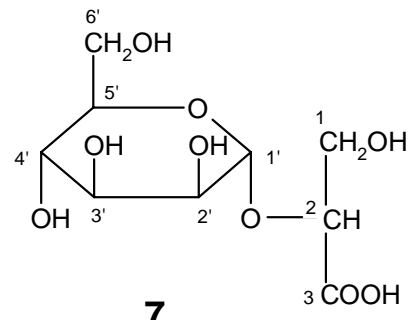

7

Figures 1-7. Compounds. 1. [4-(1'-potassium sulfate, 2,3-dibromo, 1',4,5-trihydroxybenzyl) - 4"'-(1'”-potassium sulfate, 2",3”'dibromo, 1'", 4",5"'-trihydroxybenzyl) sulfate]. 2. [1'-(2, 3-dibromo, 4-potassium sulfate, 1', 4, 5-trihydroxybenzyl) - 4"'-(1'”, potassium sulfate, 2"', 3'”-dibromo, 1'”, 4", 5' trihydroxybenzyl) sulfate]. 3. (2, 2', 3, 3'-tetrabromo-4, 4', 5, 5'tetrahydroxydiphenylmethane). 4. (2, 3-dibromo-4, 5-dihydroxybenzyl methyl ether). 4a. (2, 3, dibromo-4, 5-dihydroxybenzyl alcohol). 4b. 2, 3 dibromo, 4, 5 dimethoxibenzyl methyl ether. 5. (dipotassium 2,3-dibromo-5-hydroxybenzyl 1',4-disulfate). 6. (24-methylenecolest-5-en-3- $\beta$-ol). 7. [ $\alpha$-D-mannopyranosyl-( $\left.1 \rightarrow 2^{\prime}\right)$-glycerate].

product was submitted to preparative TLC in $\mathrm{CH}_{2} \mathrm{Cl}_{2} / \mathrm{MeOH}$ (99:1, v/v) to obtain $2 \mathbf{b}(3.1 \mathrm{mg})$ that was analyzed by ${ }^{1} \mathrm{H}$ NMR. Compound 4 (10 mg) was treated by the same procedure described for 2 a to obtain $4 \mathbf{a}(0.7 \mathrm{mg})$.

Structural analysis - Nuclear magnetic resonance (NMR) spectra were measured on spectrometers Bruker AC-200 (200 and $50 \mathrm{MHz}$ ), DPX-300 (300 and $75 \mathrm{MHz}$ ), and Bruker DRX-500 (500 and $125 \mathrm{MHz}$ ), in $\mathrm{CD}_{3} \mathrm{OD}, \mathrm{CHCl}_{3}$ and $\mathrm{D}_{2} \mathrm{O}$, with internal TMS reference.

ESI-MS analysis were carried out on a Q-TOF Micro (Micromass Ltd, Manchester, UK) mass spectrometer fitted with an electrospray ion source, operated in positive mode. The capillary voltage was $3-3.5 \mathrm{kV}$ and the sample cone voltages were $20-100 \mathrm{~V}$. $\mathrm{MS}^{2}$ experiments were performed using argon collision gas at a pressure of $3.3 \times 10^{-3} \mathrm{mbar}$, and a collision energy between 30 and $50 \mathrm{eV}$.

The infrared spectra $(\mathrm{KBr})$ were recorded with a FT-IR 1750 Perkin-Elmer spectrophotometer.

\section{Results and Discussion}

The seven substances identified in O. obtusiloba are three sulfated bromophenols (1, 2 and 5), two bromphenols (3 and 4), one sterol (6) and one glyceride (7) (figure 1).

Compounds 3, 4, 6 and 7 were identified by comparison of their spectral data with published values (Kurata \& Amiya 1977, Kubo et al. 1990, Karsten et al. 1995, Della Greca et al. 1991), respectively.

Compound 5 was analyzed for $\mathrm{C}_{7} \mathrm{H}_{4} \mathrm{O}_{9} \mathrm{Br}_{2} \mathrm{~S}_{2} \mathrm{~K}_{2}$ by elemental analysis and gave quasi molecular ion peaks $\left(\mathrm{M}^{+}\right.$532.4; 534.5 and 536.4) by electrospray ionization mass spectrometry (ESI - MS). IR spectrum indicated the presence of absorption bands due to hydroxyl groups at $3336 \mathrm{~cm}^{-1}$, phenyl rings at 1634, 1569 and $878 \mathrm{~cm}^{-1}$ and sulfate esters at 1247, 1050, 821, 634 and $589 \mathrm{~cm}^{-1}$. Its ${ }^{1} \mathrm{H}-\mathrm{NMR}$ spectrum showed a pentasubstituted aromatic ring at $\delta 7.0(1 \mathrm{H}, \mathrm{s})$ and a benzylic methoxymethylene group at $\delta 4.9,(2 \mathrm{H}, \mathrm{s})$ (table 1$)$ (Katsui et al. 1967). The carbon signals observed were: $\delta 135.3 ; 115.9 ; 122.9 ; 138.7 ; 149.7$ and 118.1 and one at $\delta 71.1$ (table 2). The IR spectrum and the elemental analysis data indicated that the sulfur was present as two sulfate ester groups. The HMQC spectrum had established correlations between the signals at $\delta 118.1$ 
Table 1. ${ }^{1} \mathrm{H}$ NMR data for compounds $\mathbf{1}, \mathbf{2}, \mathbf{2 a}, \mathbf{2 b}, \mathbf{4}, \mathbf{4 a}$, and 5.

\begin{tabular}{|c|c|c|c|c|c|c|c|}
\hline $\mathrm{H}$ & $\begin{array}{c}\mathbf{4} \\
\delta\left(\mathrm{CDCl}_{3}\right)\end{array}$ & $\begin{array}{c}\mathbf{4 a} \\
\delta\left(\mathrm{CDCl}_{3}\right)\end{array}$ & $\begin{array}{c}\mathbf{5} \\
\delta\left(\mathrm{D}_{2} \mathrm{O}\right)\end{array}$ & $\begin{array}{c}\mathbf{1} \\
\delta\left(\mathrm{D}_{2} \mathrm{O}\right)\end{array}$ & $\begin{array}{c}2 \\
\delta\left(\mathrm{D}_{2} \mathrm{O}\right)\end{array}$ & $\begin{array}{c}\mathbf{2 a} \\
\delta\left(\mathrm{CDCl}_{3}\right)\end{array}$ & $\begin{array}{c}\mathbf{2 b} \\
\delta\left(\mathrm{CDCl}_{3}\right)\end{array}$ \\
\hline \multicolumn{8}{|l|}{1} \\
\hline \multicolumn{8}{|l|}{2} \\
\hline \multicolumn{8}{|l|}{3} \\
\hline \multicolumn{8}{|l|}{4} \\
\hline \multicolumn{8}{|l|}{5} \\
\hline 6 & $7.0(\mathrm{~s}, 1 \mathrm{H})$ & $7.0(\mathrm{~s}, 1 \mathrm{H})$ & $7.0(\mathrm{~s}, 1 \mathrm{H})$ & $7.0(\mathrm{~s}, 1 \mathrm{H})$ & $7.0(\mathrm{~s}, 1 \mathrm{H})$ & $7.0(\mathrm{~s}, 1 \mathrm{H})$ & $7.0(\mathrm{~s}, 1 \mathrm{H})$ \\
\hline $1^{\prime}$ & $4.4(\mathrm{~s}, 2 \mathrm{H})$ & $4.4(\mathrm{~s}, 2 \mathrm{H})$ & $5.0(\mathrm{~s}, 2 \mathrm{H})$ & $4.9(\mathrm{~s}, 2 \mathrm{H})$ & $4.9(\mathrm{~s}, 2 \mathrm{H})$ & $4.9(\mathrm{~s}, 2 \mathrm{H})$ & $4.5(\mathrm{~s}, 2 \mathrm{H})$ \\
\hline $\mathrm{C}_{1}$ - $\mathrm{OMe}$ & $3.4(\mathrm{~s}, 3 \mathrm{H})$ & $3.4(\mathrm{~s}, 3 \mathrm{H})$ & & & & & $3.4(\mathrm{~s}, 3 \mathrm{H})$ \\
\hline $\mathrm{C}_{5}-\mathrm{OMe}$ & & $3.8(\mathrm{~s}, 3 \mathrm{H})^{*}$ & & & & & $3.8(\mathrm{~s}, 3 \mathrm{H}) *$ \\
\hline $\mathrm{C}_{4}$-OMe & & $3.9(\mathrm{~s}, 3 \mathrm{H})^{*}$ & & & & & $3.9(\mathrm{~s}, 3 \mathrm{H}) *$ \\
\hline \multicolumn{8}{|l|}{1} \\
\hline \multicolumn{8}{|l|}{$2 "$} \\
\hline \multicolumn{8}{|l|}{$3 ”$} \\
\hline \multicolumn{8}{|l|}{$4 ”$} \\
\hline \multicolumn{8}{|l|}{$5 ”$} \\
\hline $6 ”$ & & & & & $7.2(\mathrm{~s}, 1 \mathrm{H})$ & & \\
\hline 1 '” & & & & & $5.1(\mathrm{~s}, 2 \mathrm{H})$ & & \\
\hline
\end{tabular}

*Assignments may be reverse.

and $7.0(\mathrm{~s}, 1 \mathrm{H})$, and 71.1 and $4.9(\mathrm{~s}, 2 \mathrm{H})$, confirming the position of the aromatic hydrogen.

Assignment of the ring carbons was made by comparison with previously described bromophenol 2,3-dibromo-p-hydroxybenzyl methyl ether (4), whose NMR data are well established (tables 1 and 2) (Kubo et al. 1990).

The comparison of ${ }^{13} \mathrm{C}$ chemical shifts in $\mathbf{4}$ and $\mathbf{5}$ (table 2) demonstrated similarity between the substitution pattern of both pentasubstituted rings, with the two bromosubstituents in the positions 2, 3 and the dihydroxy groups at carbons 4 and 5 .

Based on these informations, only three structural alternatives represented by the models 1,2 and 3 (table 3) were possible for the compound 5. To determine the most probable one, experimentally determined carbon chemical shifts of 5 were compared with calculated ${ }^{13} \mathrm{C}$ NMR shifts obtained by replacement of $\mathrm{OH}$ - by $\mathrm{OSO}_{3} \mathrm{~K}$ groups on 2, 3-dibromo-phydroxybenzyl methyl ether molecule. These substituent effects are: ipso -2.8 ; orto +7.8 ; meta +1.6 and para +7.4 (Jensen \& Ragan 1978).

The calculated ${ }^{13} \mathrm{C}$ NMR shifts are in good agreement with the observed ones for model 1, being within the accuracy of the employed method (Jensen \& Ragan 1978). So, 5 is identified as 2,3-dibromo-5hydroxybenzyl 1',4-disulfate (model 1).
Compound 1 was an amorphous brown powder that rapidly oxidizes in air. Its quasi molecular formula for $\mathrm{C}_{14} \mathrm{H}_{8} \mathrm{O}_{14} \mathrm{Br}_{4} \mathrm{~S}_{3} \mathrm{~K}_{2}$ was deduced from the $[\mathrm{M}+\mathrm{H}]^{+}$ion at $\mathrm{m} / \mathrm{z} 970.3$ in the electrospray ionization mass spectra (ESI-MS), as well as from the elemental analysis data. The IR spectrum showed the presence of groups $\mathrm{OH}$ at $3434 \mathrm{~cm}^{-1}$, phenyl ring at $1469 \mathrm{~cm}^{-1}$ and sulfate groups at $1274,1230,1063,852,643$ and $589 \mathrm{~cm}^{-1}$.

The ${ }^{13} \mathrm{C}$ NMR showed six aromatic carbons at $\delta$ 150.7, 139.4, 136.4, $118.9(\mathrm{CH}), 116.6$ and a methylenic one at 71.7 (table 2); the ${ }^{1} \mathrm{H}$ NMR spectrum displayed two signals (each singlet) at $\delta 7.0$, due to an aromatic proton and at $\delta 5.0$ due to a methylenic group, the later band of double intensity in relation to the former (table 1). These NMR spectra showed the presence of a 2,3-dibromo-4,5-dihydroxy benzene moiety and were very similar to those of $\mathbf{5}$. However, there were some significant differences between them for mass spectra, which strongly suggested that $\mathbf{1}$ must contain two lanosol units put together in a symmetric way. Taking into account the existence of two potassium ions and three sulfur atoms in the molecule (two $\mathrm{OSO}_{3}{ }^{-} \mathrm{K}^{+}$groups), symmetrical considerations require that one sulfur atom must pertain to the linkage between the two 2,3-dibromo-4,5-dihydroxy benzene moieties; therefore, the structure of this molecule should be represented by structure 1 . 
Table 2. ${ }^{13} \mathrm{CNMR}$ data for compounds $\mathbf{1}, \mathbf{2 , 4} \mathbf{4}, \mathbf{4 a}$, and $\mathbf{5}$.

\begin{tabular}{|c|c|c|c|c|c|}
\hline C & $\begin{array}{c}1 \\
\delta\left(\mathrm{D}_{2} \mathrm{O}\right)\end{array}$ & $\begin{array}{c}2 \\
\delta\left(\mathrm{D}_{2} \mathrm{O}\right)\end{array}$ & $\begin{array}{c}\mathbf{4} \\
\delta\left(\mathrm{CDCl}_{3}\right)\end{array}$ & $\begin{array}{c}\mathbf{4 a} \\
\delta\left(\mathrm{CDCl}_{3}\right)\end{array}$ & $\begin{array}{c}5 \\
\delta\left(\mathrm{D}_{2} \mathrm{O}\right)\end{array}$ \\
\hline 1 & 136.4 & 135.7 & 130.0 & 135.2 & 135.3 \\
\hline 2 & 116.6 & 118.4 & 114.0 & 114.8 & 115.9 \\
\hline 3 & 123.6 & 123.2 & 113.0 & 121.6 & 122.9 \\
\hline 4 & 139.4 & 140.7 & 142.9 & 146.6 & 138.7 \\
\hline 5 & 150.7 & 151.7 & 144.2 & 152.6 & 149.7 \\
\hline 6 & $118.9(\mathrm{CH})$ & $116.0(\mathrm{CH})$ & $114.8(\mathrm{CH})$ & $111.2(\mathrm{CH})$ & $118.1(\mathrm{CH})$ \\
\hline 1' & 71.7 & 72.0 & 74.5 & 74.7 & 71.1 \\
\hline $\mathrm{C}_{1},-\mathrm{OMe}$ & & & 57.9 & 56.2 & \\
\hline $\mathrm{C}_{5}$-OMe & & & & $60.5^{*}$ & \\
\hline $\mathrm{C}_{6}^{5}$-OMe & & & & $60.6^{*}$ & \\
\hline $1 ”$ & & 136.6 & & & \\
\hline 2" & & 114.6 & & & \\
\hline 3" & & 124.0 & & & \\
\hline 4" & & 138.6 & & & \\
\hline 5” & & 150.3 & & & \\
\hline 6” & & $116.9(\mathrm{CH})$ & & & \\
\hline 1 '” & & 71.5 & & & \\
\hline
\end{tabular}

*Assignments may be reverse.

Compound 2 was also a solid soluble in water that oxidizes in air. Elemental analysis and mass spectrometric measures (ESI - MS) established molecular composition of $\mathrm{C}_{14} \mathrm{H}_{8} \mathrm{O}_{14} \mathrm{Br}_{4} \mathrm{~S}_{3} \mathrm{~K}_{2}\left(\mathrm{M}^{+}\right.$at m/z 966.43, 968.36, 970.42, 974.35 and 976.35) for this substance. The IR spectrum (KBr) (3479; 1450; 1256 , 1196, 1051, 874, 656 and $577 \mathrm{~cm}^{-1}$ ) suggested the presence of phenolic ring and sulfate groups, similarly to compounds $\mathbf{5}$ and $\mathbf{1}$.

The ${ }^{1} \mathrm{H}$ NMR spectrum of $2\left(\mathrm{D}_{2} \mathrm{O}\right)$ showed four peaks: $\delta 7.2(\mathrm{~s}, 1 \mathrm{H}), 7.0(\mathrm{~s}, 1 \mathrm{H}), 4.9(\mathrm{~s}, 2 \mathrm{H})$ and 5.1 (s, 2H) (table 1); the ${ }^{13} \mathrm{C}$ NMR spectra showed 12 aromatic and 2 methylenebenzylic peaks (table 2).

The examination of the 12 aromatic carbon NMR signals of 2 revealed two distinct sets of signals (each set belonging to an aromatic ring) that were nearly identical to the aromatic carbons of 5, leading to the conclusion that these two rings have the same substitution pattern (table 2).

The acid hydrolysis of compound $\mathbf{2}$ furnished $\mathbf{2 a}$ whose ${ }^{1} \mathrm{H}$ NMR $\left(\mathrm{CDCl}_{3}\right)$ spectrum showed only one peak in $\delta 7.0$ (aromatic region), suggesting that both aromatic rings became magnetically equivalent (table 1 ). Methylation of $\mathbf{2 a}$ gave the compound $\mathbf{2} \mathbf{b}$ which ${ }^{1} \mathrm{H}$ NMR spectrum $\left(\mathrm{CDCl}_{3}\right)$ presented a series of singlets at $\delta 7.0$ (aromatic), 4.5, 3.9 and 3.8 that matched with the signals observed in the ${ }^{1} \mathrm{H}$ NMR spectrum for methylated lanosol (table1) (Katsui et al. 1967). These facts suggested that the compound $\mathbf{2}$ is constituted by two 2,3-dibromo-4,5-dihydroxybenzylic groups, arranged in an asymmetrical way.

According to elemental analysis, there are three sulfur atoms and two potassium ions in this molecule, and consequently two $\mathrm{OSO}_{3}{ }^{-} \mathrm{K}^{+}$groups, besides a plain $-\mathrm{OSO}_{3}$. Carefully consideration of all these data allowed us to propose the structure 2 for this new bromophenol.

As previously suggested (Weinstein et al. 1975), sulfated bromophenols may currently exist in red algae and be responsible for the wide variety of bromophenols described in the literature that may arise as a result of either natural or artificial decomposition during the fractionation of the algal extracts.

We consider that it was possible to isolate $\mathbf{1}$ and $\mathbf{2}$ because of the mild conditions employed in the extraction and in the samples concentration and because of the use of the sorbent XAD-2; this polymer is applied for the isolation of sulfated substances from biological samples (Lingeman \& Tjaden 1990) and considered efficient for the separation of phenolic polymers from algal extracts (Gregson \& Daly 1982).

Compound 4 (2, 3-dibromo-p-hydroxybenzyl methyl ether) was previously reported to display antialgal and anti-inflammatory properties, to influence growth and morphology of algae and to stimulate lettuce and rice seeds growth (Carvalho \& Roque 2000). 
Table 3. Observed ${ }^{13} \mathrm{C}$ NMR chemical shifts ( $\delta$ ) for compounds 4 and 5 and predicted for models 1,2 and 3 and $\delta \Delta_{\mathrm{n}}$.

\begin{tabular}{|c|c|c|c|c|c|c|c|c|}
\hline $\begin{array}{l}\text { Carbon } \\
\text { number }\end{array}$ & $\begin{array}{c}\text { Compound } 4 \\
\left(\mathrm{CDCl}_{3)}\right.\end{array}$ & $\begin{array}{c}\text { Compound } 5 \\
\left(\mathrm{D}_{2} \mathrm{O}\right)\end{array}$ & Model 1 & & Model 2 & & Model 3 & \\
\hline C-1 & Observed & Observed & Predicted & $\delta \Delta_{1}$ & Predicted & $\begin{array}{l}\delta \Delta_{2} \\
-37\end{array}$ & Predicted & $\delta \Delta_{3 .}$ \\
\hline $\mathrm{C}-2$ & 114.0 & 115.9 & 115.6 & -0.3 & 121.4 & 5.5 & 123.0 & 7.1 \\
\hline C-3 & 113.0 & 122.9 & 120.8 & -2.1 & 114.6 & -8.3 & 122.4 & -0.5 \\
\hline$C-4$ & 142.9 & 138.7 & 139.5 & 0.7 & 150.7 & 12.0 & 147.9 & 9.2 \\
\hline C-5 & 144.2 & 149.7 & 152.0 & 2.3 & 141.4 & -8.3 & 149.2 & -0.5 \\
\hline C-6 & $114.8(\mathrm{CH})$ & $118.1(\mathrm{CH})$ & 116.4 & -1.7 & 122.6 & 4.5 & 124.2 & 6.1 \\
\hline \multicolumn{4}{|c|}{$\Sigma$ [predicted - observed] } & 1.1 & & 1.7 & & 25.1 \\
\hline
\end{tabular}

$\delta \Delta_{\mathrm{i}}=$ differences between predicted shifts for models 1,2 and 3 and observed signals of compound $\mathbf{5}$.

Acknowledgments - S.M.P.B. Guimarães thanks CNPq for the research fellow grant

\section{References}

CARVALHO, L.R. \& ROQUE, N.F. 2000. Halogenated and/or sulphated phenols from marine macroalgae. Química Nova 23:757-764.

DELLA GRECA, M., MONACO, P. \& PREVITERA, L. 1991. New oxigenated sterols from Eichhornia crassipes Solms. Tetrahedron 47:7129-7134.

FAULKNER, D.J. 1984. Marine Natural Products. Natural Products Reports 1:251-280.

FAULKNER, D.J. 1986. Marine Natural Products. Natural Products Reports 3:1-34.

FAULKNER, D.J. 1990. Marine Natural Products. Natural Products Reports 7:269-310.

FAULKNER, D.J. 1991. Marine Natural Products. Natural Products Reports 8:97-147.

FAULKNER, D.J. 1992. Marine Natural Products. Natural Products Reports 9:323-364.

FAULKNER, D.J. 1993. Marine Natural Products. Natural Products Reports 10:497-539.

FAULKNER, D.J. 1996. Marine Natural Products. Natural Products Reports 13:75-125.

FAULKNER, D.J. 1998. Marine Natural Products. Natural Products Reports 15:113-158.

FAULKNER, D.J. 2000. Marine Natural Products. Natural Products Reports 17:7-55.

FAULKNER, D.J. 2001. Marine Natural Products. Natural Products Reports 18:1-49.

FAULKNER, D.J. 2002. Marine Natural Products. Natural Products Reports 19:1-48.
GREGSON, R.P. \& DALY, J.J. 1982. Polyhydroxy biphenyl ethers from the brown alga Cystophora congesta. Australian Journal of Chemistry 35:647-657.

HARAGUCHI, M. 1991. Técnicas modernas de separação em química de produtos naturais. Instituto Biológico, São Paulo.

HIGA, T. 1981. Phenolic substances. In Marine Natural Products. Chemical and biological perspectives. (P.J Scheuer, ed.). Academic Press, New York, p.93-145.

JENSEN, A. \& RAGAN, M. 1978. 1,2,3,5-Tetrahydroxybenzene 2,5-disulfate ester: the phenolic precursor in gelbstoffforming exudates from the marine brown alga Ascophyllum nodosum (L.) Lejol. Tetrahedron Letters 9:847-850.

KARSTEN, U., BOCK, C. \& WEST, J.A. $1995 .{ }^{13}$ C-NMR spectroscopy as a tool to study organic osmolytes in the mangrove red algal genera Bostrychia and Stictosiphonia (Ceramiales). Phycological Research 43:241-247.

KATSUI, N., SUZUKI, Y., KITAMURA, S. \& IRIE, T. 1967. 5,6-Dibromoprotocatechualdehyde and 2,3-dibromo-4,5dihydroxybenzyl methyl ether. New bromophenols from Rhodomela larix. Tetrahedron 23:1185-1188.

KAZLAUSKAS, R., MURPHY, P.T. \& WELLS, R.J. 1982. A brominated metabolite from the red alga Vidalia spiralis. Australian Journal of Chemistry 35:219-220.

KORNPROBST, J.M., SALLENAVE, C. \& BARNATHAN, G. 1998. Sulfated compounds from marine organisms. Comparative Biochemistry and Physiology 199B:1-51.

KUBO, I., OCHI, M., SHIBATA, K., HANKE, F.J., NAKATSU, T., TAN, K.S., TANIGUCHI, M., KAMIKAWA, T., YAMAGIWA, Y., ARIZUKA, M. \& WOOD, W.F. 1990. Effect of a marine algal constituent on the growth of lettuce and rice seedlings. Journal of Natural Products 53:50-56. 
KUHIRAHA, H., MITANI, T., KAWABATA, J. \& TAKAHASHI, K. 1999. Two new bromophenols from the red alga Odonthalia corymbifera. Journal of Natural Products 62:882-884.

KURATA, K. \& AMIYA, T. 1977. Two new bromophenols from the red alga Rhodomela larix. Chemical Letters 1435-1438.

KURATA, K. \& AMIYA, T. 1980. Disodium 2,3,6-tribromo-5hydroxybenzyl 1', 4-disulfate, a new bromophenol from the red alga Symphyocladia latiuscula. Chemical Letters 279-280.

KURATA, K., TANIGUCHI, K., TAKASHIMA, K., HAYASHI, I. \& SUZUKI, M. 1997. Feeding-deterrent bromophenols from Odonthalia corymbifera. Phytochemistry 45:485-487.

LINGEMAN, H. \& TJADEN, U.R. 1990. Sample pretreatment procedures. In Detection-oriented derivatization techniques in liquid chromatograph $(\mathrm{H}$. Lingeman \& W.J.M Underberg, eds.). Marcel Dekker INC., New York, p.85-151.
PATTI, A. \& MORRONE, R. 1992. Biosynthetic relationship between sulfonium and $\mathrm{N}$-methylated compounds in the red alga Vidalia volubilis. Journal of Natural Products 55:53-57.

PIERTRZYK, D.J. 1989. Organic polymeric stationary phases. In High performance liquid chromatography. (P.R. Brown $\&$ R.A. Harttwick, eds.). Wiley Interscience Publication, New York, p.223-276.

SMIT, A.J. 2004. Medicinal and pharmaceutical uses of seaweed natural products: a review. Journal of Applied Phycology 16:245-262.

YOO, H.D., KETCHUM, S.O., FRANCE, D., BAIR, K. \& GERWICK, W.H. 2002. Vidalenona, a novel phenolic metabolite from the tropical red alga Vidalia sp. Journal of Natural Products 65:51-53.

WEINSTEIN, B., ROLD, T.L., HARRELL JUNIOR, C.E., BURNS III, M.W. \& WAALAND, J.R. 1975. Reexamination of the bromophenols in the alga Rhodomela larix. Phytochemistry 14:2667-2670.

WIEMER, D.F., IDLER, D.D. \& FENICAL, W. 1991. Vidalols A and $\mathrm{B}$, new anti-inflammatory bromophenols from the Caribbean marine alga Vidalia obtusiloba. Experientia 47:851-853. 